(RESEARCH ARTICLE)

\title{
Physical parameters and physico-chemical properties of two wild beans (Phaseolus lunatus) consumed in Côte d'Ivoire
}

\author{
Ekissi Elvis Gbocho Serge 1,*, Yapi Jocelyn Constant ${ }^{2}$, Kouadio Martin Tanoh ${ }^{1}$, Gouledji Albert Abidie ${ }^{1}$ and \\ Kouame Patrice Lucien ${ }^{1}$ \\ ${ }^{1}$ Laboratory of Biochemistry and Food Technology, University Nangui Abrogoua (Abidjan, Côte d'Ivoire). \\ ${ }^{2}$ Department of Biochemistry and Microbiology, Agroforestry unit, University Lorougnon Guede (Daloa, Côte d'Ivoire).
}

Publication history: Received on 11 August 2019; revised on 14 September 2019; accepted on 16 September

2019 Article DOI: https://doi.org/10.30574/wjarr.2019.3.2.0049

\begin{abstract}
In Côte d'Ivoire, many varieties of wild beans are frequently consumed. This study was conducted to know the physical parameters (length, width, thickness and weight) and some physicochemical properties of two varieties (white and red) of beans (Phaseolus lunatus). The lengths varied from $11.2 \pm 0.2$ to $9.6 \pm 1.6 \mathrm{~mm}$, widths from $7.9 \pm 0.6$ to $9.6 \pm 1.6$, thickness from $4.5 \pm 0.3$ to $5.0 \pm 0.6$ and weight from $715 \pm 0.03$ to $931 \pm 0.07 \mathrm{~g}$. The capacities and hydration index varied respectively from $0.29 \pm 0.00$ to $0.40 \pm 0.01 \mathrm{~g} / \mathrm{seed}$, from $0.40 \pm 0.01$ to $0.66 \pm 0.01$. The capacities and solubility index varied respectively from $0.28 \pm 0.01$ to $0.45 \pm 0.02 \mathrm{ml} / \mathrm{seed}$, from $0.65 \pm 0.4$ to $0.875 \pm 0.66$. The bean densities are $1.27 \pm 0.01$ (white) and $1.32 \pm 0.01$ (Red). Cooking times of bean seeds ranged from $45 \pm 2$ (White) to $48 \pm 2$ min (Red). Major physicochemical properties of bean flours are carbohydrates $(54.89 \pm 0.54-63.03 \pm 0.9 \mathrm{mg} / 100 \mathrm{~g})$, protein $(23.90 \pm 0.43-$ $24.10 \pm 0.71 \mathrm{mg} / 100 \mathrm{~g})$ and fibers $(5.35 \pm 0.45-5.45 \pm 0.45 \mathrm{mg} / 100 \mathrm{~g})$. The majority minerals in bean flours are potassium (1444.7 $\pm 4.8-1206.7 \pm 2.9 \mathrm{mg} / 100 \mathrm{~g}$ ), phosphorus (412 $\pm 27-451.91 \pm 14.6 \mathrm{mg} / 100 \mathrm{~g})$ and calcium (268 $\pm 0.12-297-84 \pm 2.4$ $\mathrm{mg} / 100 \mathrm{~g})$. The $\mathrm{Ca} / \mathrm{P}$ and $\mathrm{Na} / \mathrm{K}$ ratios of bean varieties flours are less than 1.
\end{abstract}

Keywords: Bean; Physical parameters; Phaseolus lunatus; Physico-chemical; Variety

\section{Introduction}

Lima bean (Phaseolus lunatus L.) is one of the five cultivated Phaseolus bean species, which originated in the Americas [1,2] and have been grown in the New World Tropics for up to ten thousand years [3]. Phaseolus lunatus belongs to the family Leguminosae, commonly known as lima bean is one of the important leguminous crops in the genus phaseolus noted for its nutritional and medicinal properties. They are a type of legume native to South American [4].

Although lima beans (P. lunatus) are less widely cultivated, they are a very important alternative source of income and food for local populations in regions such a northeastern Brazil [5]. Lima bean is cultivated primarily for its immature and dry seeds, which in tropical Africa are usually eaten boiled, fried in oil or baked. Beans are an important food crop both from the economic and nutritional points of view, and are cultivated and consumed worldwide [6]. As a result, dry beans are used throughout the world representing $50 \%$ of the grain legumes consumed as a human food source. Bean forms a good source of income for farm families [7]. The varietal differences exist insize (small and large) and colour, usually ranging from green to creamy white and a phenomenal starchy flavor [8]. Lima bean like all other legumes are food resources that offer various optimum nutritional and/ or health benefits [9].

Legumes are all plants of the pea and beans family (Leguminoceae) which comprises the Caesalpinacea (Senna family), Mimosaceae (Locust bean) and Pappilionaceae [10]. They are of economic importance as cheap sources of protein, energy and other nutrients in the diets in most developing countries of the world. Legumes have been categorized either

\footnotetext{
${ }^{*}$ Corresponding author

E-mail address: ekiss_esg@yahoo.com
} 
as major or minor based on their utilization. The major legumes include soybean, groundnut, cowpea, African locust bean while the usually regarded as miscellaneous, neglected or underutilized include Bambara groundnut, lima beans, pigeon peas, etc [11]. They are a rich source of proteins, complex carbohydrates, dietary fibres and minerals, but they also contain biologically active phytochemicals that are important for human health [12]. The major legumes have received much research attention unlike the minor legumes.

In Côte d'Ivoire, various varieties of wild beans are consumed and their nutritional potential are often inexistent or unknown. The aim of this study is to characterize the parameters (physical and physicochemical) of two varieties (purple and white) of wild beans to better understand their biochemical composition.

\section{Material and methods}

\subsection{Sample Collection}

The purple and white varieties (figure 1) of wild beans (Phaseolus lunatus) used in this study were collected at Bouaké (Center, Côte d'Ivoire). In this region, some populations use the bean plants for other purposes (fencing of houses, embellishment ...). These two varieties of beans were identified at the floristic center of Felix Houphouët Boigny University (Abidjan, Côte d'Ivoire). At maturity, the beans were removed from all impurities and taken to the laboratory of Biochemistry and Food Technology of Nangui Abrogoua University (Abidjan, Côte d'Ivoire) for analyzes.
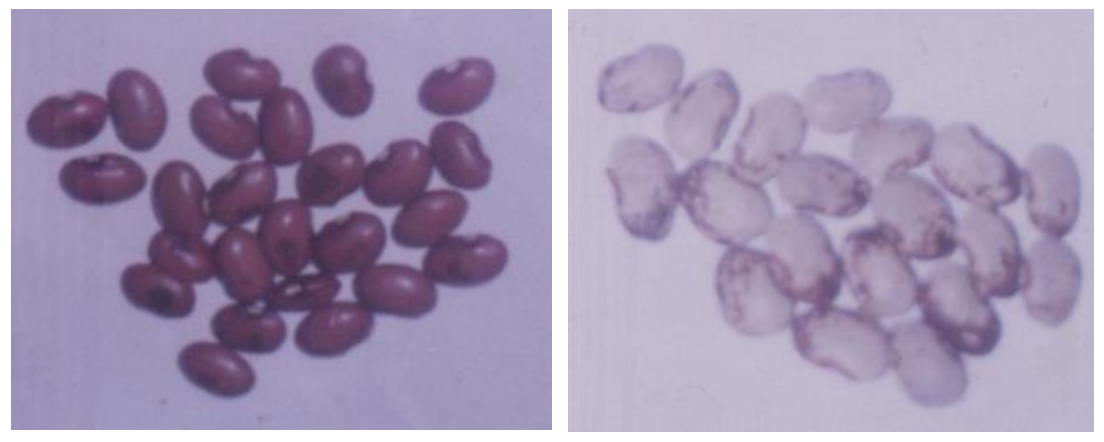

Figure 1 The two varieties (purple and white) of wild beans (Phaseolus lunatus)

\subsection{Flours preparation}

For each batch, a sufficient quantity (one kilogram) of bean seeds was taken, rinsed four times with deionized water, dried in a ventilated oven at $55{ }^{\circ} \mathrm{C}$ for $24 \mathrm{~h}$, ground in an analytical flour mill and sieved with a sieve of $200 \mu \mathrm{m}$ in diameter. The two bean (purple and white) flours obtained were stored in plastic containers and stored in the laboratory prior to use.

\subsection{Physical measurements}

The followings were the tools and equipment employed: Weights of the samples were determined by using a precision electronic balance reading to an accuracy of $0.01 \mathrm{gm}$. To determine the average size of the seed, 100 seeds were randomly picked out of 120 seeds samples for Uyole-96 and their three principle dimensions (lengths, width, and thickness) were measured using a digital vernier caliper with an accuracy of $0.01 \mathrm{~mm}$ [13].

Hundred randomly selected seeds were used to measure length (L), breadth (B) and thickness (T), three principal dimensions which are in the three mutually perpendicular directions using A Vernier caliper reading $0.01 \mathrm{~mm}$. 1000seed weight was determined by counting one hundred seeds manually and weighing. The obtained values were then multiplied by a factor 10 to get 1000-seed weight [14]. Cooking time was determined according to the method [15].The seeds were weighed and cooked at $65^{\circ} \mathrm{C}$ with $550 \mathrm{ml}$ of distilled water.

\subsection{Hydration Capacity and Hydration Index}

Seeds (10 g) were soaked in $100 \mathrm{ml}$ of distilled water in a measuring cylinder and covered with an aluminum foil. The seeds were left to soak for $24 \mathrm{~h}$ in room temperature $\left(25^{\circ} \mathrm{C}\right)$; drained and excess water was removed using a tissue paper. The weight of the swollen seeds was measured. Hydration capacity and hydration index were calculated [16]. 
Ekissi et al. / World Journal of Advanced Research and Reviews, 2019, 03(02), 007-016

$$
\text { Hydration capacity }=\frac{\text { Weight after soaking }- \text { Weight before soaking }}{\text { Number of seed }}
$$

$$
\text { Hydration index }=\frac{\text { Hydration capacity of seed }}{\text { Weight of one seed }}
$$

\subsection{Swelling Capacity and Swelling Index}

The volume of $5 \mathrm{~g}$ of seeds was predetermined using a graduated cylinder and they were subsequently soaked overnight in distilled water. The volume of the seeds after soaking was then measured. Swelling capacity and the swelling index were determined [16].

$$
\text { Swelling capacity }=\frac{\text { Volume after soaking }- \text { Volume before soakingg }}{\text { Number of seed }}
$$

$$
\text { Swelling index }=\frac{\text { Swelling capacity of seed }}{\text { Number of seed }}
$$

\subsection{Density}

Seeds (100 g) of the sample after accurately weighing, and transferred to a measuring cylinder, where $100 \mathrm{ml}$ distilled water at $20^{\circ} \mathrm{C}$ is added. Seed volume (ml/100 g seeds) was obtained after subtracting $100 \mathrm{ml}$ from the total volume $(\mathrm{ml})$. Volume increase measured immediately, so that swelling character not a problem. The density of bean seeds was calculated and recorded as $\mathrm{g} / \mathrm{ml}[17]$.

\subsection{Physicochemical analyzes}

Proximate chemical composition analysis of the seed flour including moisture, total ash; crude protein $(\mathrm{N} \times 6.25)$, fibers, fat and starch content were performed [18]. Total and reducing sugars contents were carried out [19, 20]. Total carbohydrate contents were evaluated [21]. Total carbohydrates excluding crude fiber were calculated by difference. Caloric energy was calculated according to Atwater general factor system [22]. The system uses a single factor for each of the energy-yielding substrates (protein, fat, carbohydrate) regardless of the food in which it is found. The energy values are $4.0 \mathrm{kcal} / \mathrm{g}$ for protein, $9.0 \mathrm{kcal} / \mathrm{g}$ for fat and $4.0 \mathrm{kcal} / \mathrm{g}$ for carbohydrates.

Minerals such as calcium (Ca), sodium (Na), potassium (K), iron (Fe) and phosphorus (P) were quantified by Atomic Absorption Spectrometer (Varian AA 20, Australia) and Spectrophotometer (UV/Visible Jasco V 530i) respectively, after digestion of samples $[23,24]$. The $\mathrm{Ca} / \mathrm{P}$ and $\mathrm{Na} / \mathrm{K}$ ratios was evaluated by calculation.

\subsection{Statistical analysis}

All analyses were performed in triplicates. Results were expressed by means of \pm standard deviation. Statistical significance was established using Analysis of Variance (ANOVA) models to estimate the properties and parameters of bean flours. Means were separated according to Duncan's multiple range analysis ( $\mathrm{p}<0.05)$, with the help of the software Statistica (StatSoft Inc, Tulsa USA Headquarters) [25].

\section{Results and discussion}

\subsection{Physical parameters}

Physic parameters of bean varieties (Phaseolus lunatus) flours are presented in table 1. Physical and mechanical properties are prerequisites in the design of suitable systems, machines, and structures for planting, harvesting, handling, processing, and storing of agro-products $[26,27]$. This knowledge is important in the designing of machinery to harvest and in preparation of processing chain from grain to food. Knowledge of physical properties of agriculturally, nutritionally, and industrially valuated seed materials is imperative in designing the equipment for harvest, transport, storage, processing, cleaning, hulling, and milling [28, 29]. 
The length of bean seeds ranged from $11.2 \mathrm{~mm}$ (purple variety) to $15.2 \mathrm{~mm}$ (white varieties). Seed width ranged from $7.9 \mathrm{~mm}$ to $9.2 \mathrm{~mm}$, and widths ranged from $4.5 \mathrm{~mm}$ (purple variety) to $5.0 \mathrm{~mm}$ (purple variety). There were significant differences in size (length and width) of seeds with the exception of thickness. Bean seeds (Phaseolus lunatus) are similar in size [30], [13] for different red bean cultivars. The thousand (1000) seed weight differed significantly $(P<0.05)$ among all the two accessions with a range from $715.00 \mathrm{~g}$ for red bean to $931.00 \mathrm{~g}$ for white bean (table 1 ). The results are far higher than those reported [31] for three cowpea cultivars with 1000-seed weight in the range of 131.6-151.6 g. Additionally, [32] have reported 1000 seed mass for certain cowpea seeds in the range between $140.44 \mathrm{~g}$ and 192.81 g. The seed weight of bean (Phaseolus lunatus) variety could be a useful criterion for determining suitability for a particular end-use application. For example, varieties with large seeds would be preferred for canning, since this would mean less quantity of beans would be required to attain a high cooked bean weight. Furthermore, classification based on seed weight may be used to determine conformity to standards during quality control of raw materials. [33] identified five morphotypes of lima bean on the basis of hundred-seed weight, seed length, and seed width.

Table 1 Physic parameters of bean varieties (Phaseolus lunatus) flours

\begin{tabular}{lll}
\hline $\begin{array}{l}\text { Physic parameters } \\
(\mathbf{m m})\end{array}$ & $\begin{array}{c}\text { Bean varieties } \\
\text { Purple }\end{array}$ & White \\
\hline Length & $11.2 \pm 0.2^{\mathrm{a}}$ & $15.2 \pm 1.4^{\mathrm{b}}$ \\
Breadt & $7.9 \pm 0.6^{\mathrm{a}}$ & $9.6 \pm 1.6^{\mathrm{b}}$ \\
Tchickness & $4.5 \pm 0.3^{\mathrm{a}}$ & $5.0 \pm 0.6^{\mathrm{b}}$ \\
1000 -seeds weight $(\mathrm{g})$ & $715 \pm 0.03^{\mathrm{a}}$ & $931 \pm 0.07^{\mathrm{b}}$ \\
\hline \multicolumn{2}{r}{ Values are means of triplicate determinations \pm standard deviation }
\end{tabular}

\subsection{Physico-chemical properties}

Physical properties and cooking time of bean varieties (Phaseolus lunatus) flours are presented in table 2. Significant differences $(\mathrm{P}<0.05)$ were observed among the bean varieties for hydration and swelling capacities as well as hydration and swelling indices. White beans had the highest swelling index $(0.875 \pm 0.06)$ whereas purple beans the lowest $(0.652 \pm 0.043)$. High value of swelling index revealed high swelling ability of white seeds. The swelling ability of any seed depends upon its water retention capacity or hydration capacity. The hydration capacity of white bean seed was found to be $0.404 \pm 0.011 \mathrm{~g} / \mathrm{seed}$. The increase in the swelling capacity of white bean samples $(0.451 \pm 0.022 \mathrm{~mL} / \mathrm{seed})$ could be due to their high protein contents [34]. Hydration capacity and hydration index of bean cultivars have been reported to vary between $0.31-0.59 \mathrm{~g} / \mathrm{seed}$ and $0.78-1.25$ respectively [35]. Hydration capacity determines the extent to which seeds absorb water on soaking. It depends upon chemical composition of seed coat and cotyledons [36]. The high swelling capacities of these beans will make them useful in the preparation of soups, puddings, and sauces.

Elevated hydration and swelling capacities of white bean shows their softness and high permeability. Also, a large hydration capacity leads to better cooking quality (less cooking time and texture). As cooking of white bean variety would require less fuel and energy, it should be preferred. The hydration index of red bean $(0.402 \pm 0.002)$ was less than those of white bean varieties $(0.657 \pm 0.001)$. These differences may be attributed to difference in size, seed coat thickness, and water absorption characteristics of seeds [37]. The seed density of purple bean seeds (1.317 $\pm 0.012 \mathrm{~g} /$ $\mathrm{mL}$ ) was higher than those of white bean $(1.270 \pm 0.025 \mathrm{~g} / \mathrm{mL})$. The density of dry beans was higher than $1 \mathrm{~g} / \mathrm{mL}$ indicating that the seeds are heavier than water and hence sink. The values were statistically different $(P<0.05)$. [38] analyzed some samples of common bean and found that mean value of seed density was around $1.25 \mathrm{~g} / \mathrm{mL}$. The results obtained for cooking properties of haricot bean (Phaseolus lunatus) are given in Table 3. Cooking time is one of the main considerations used for evaluating pulse cooking quality. Longer cooking times result in a loss of nutrients and could limit end-uses. Hence, consideration of cooking time is of paramount importance. White bean and purple bean varieties required the minimum and maximum cooking time of $45.00 \pm 2$ and $48.00 \pm 2 \mathrm{~min}$, respectively. As white bean varieties, had higher hydration and swelling capacities, he required less cooking time. The hardness of the cooked bean is defined, as the maximum force required for $75 \%$ deformation of seeds after cooking. The force required for seed deformation was less for white bean and this variety also had the smallest cooking time. 
Ekissi et al. / World Journal of Advanced Research and Reviews, 2019, 03(02), 007-016

Table 2 Physical properties and cooking time of bean varieties (Phaseolus lunatus) flours

\begin{tabular}{lll}
\hline Physical properties & $\begin{array}{l}\text { Bean varieties } \\
\text { Purple }\end{array}$ & White \\
\hline Hydratation capacity (g/seed) & $0.29 \pm 0.00^{\mathrm{a}}$ & $0.40 \pm 0.01^{\mathrm{b}}$ \\
Hydratation index & $0.40 \pm 0.01^{\mathrm{a}}$ & $0.66 \pm 0.01^{\mathrm{b}}$ \\
Swelling capacity (mL/seed) & $0.28 \pm 0.01^{\mathrm{a}}$ & $0.45 \pm 0.02^{\mathrm{b}}$ \\
Swelling index & $0.65 \pm 0.04^{\mathrm{a}}$ & $0.87 \pm 0.06^{\mathrm{b}}$ \\
Density & $1.32 \pm 0.01^{\mathrm{a}}$ & $1.27 \pm 0.01^{\mathrm{b}}$ \\
Cooking times (min) & $48 \pm 2^{\mathrm{a}}$ & $45 \pm 2^{\mathrm{b}}$ \\
\hline \multicolumn{2}{c}{ Values are means of triplicate determinations \pm standard deviation }
\end{tabular}

\subsection{Proximate composition}

The proximate composition of two varieties beans (Phaseolus lunatus) is presented in table 3 . For the two varieties, significant differences $(P<0.05)$ were observed in some nutrient contents (moisture, carbohydrates, starch, total sugar, reducing sugar).

Moisture content of beans ranged from $10.33 \pm 0.02$ to $19.8 \pm 0.01 \mathrm{mg} / 100 \mathrm{~g}$ for purple and white varieties beans respectively. Moisture content estimates directly the water content and indirectly the dry matter content of the sample. It is also an index of storage stability of the flour. Flour with moisture content less than $14 \%$ can resist microbial growth and thus has better storability $[39,40]$. The results show that the moisture contents range was within those [41] for barley grains which was 7.34 to $21.58 \mathrm{mg} / 100 \mathrm{~g}$ and for fennel seed (Foeniculum vulgare) which were between $7.78 \%$ to $21.67 \mathrm{mg} / 100 \mathrm{~g}$ [42]. However, the moisture content is mainly dependent on drying and storage conditions, but not due to variety.

There was no significant difference between the protein content of both the samples (Table 3). Protein is an essential nutrient ranks second place after water in occupying most plentiful substance in our body. The results show that the two beans (purple and white) are rich source of protein as compared to red gram (22.3 mg/100g), Bengal gram (20 $\mathrm{mg} / 100 \mathrm{~g}$ ) and green gram $(24 \mathrm{mg} / 100 \mathrm{~g})$ which are commonly consumed in India [43]. The mean protein of two beans varieties content was higher to what has been reported in other studies elsewhere $[44,45,46]$.

Fat content in the two samples was low $(0.80 \pm 0.05-0.81 \pm 0.01 \mathrm{mg} / 100 \mathrm{~g})$ and in agreement with other observations for lablab beans $[47,48]$ and other commonly consumed legume grains $[49,50,51,52]$.

The relatively high carbohydrates content and energy values of the beans seeds observed in this study are similar to those observed in other studies $[53,54,55]$. They are also within the range of the other most commonly consumed legume grains [56]. The highest carbohydrate content $(63.03 \pm 0.9 \mathrm{mg} / 100 \mathrm{~g})$ was reported for red bean varieties and the lowest for white bean $(54.89 \pm 0.54 \mathrm{mg} / 100 \mathrm{~g})$. Significant differences were found in carbohydrate content among the varieties. Comparable results for composition of bean have been reported [57]. The differences in composition of beans (Phaseolus lunatus) could be due to the genetic differences.

Total ash content in two varieties was between $4.37 \pm 0.19$ (purple variety) and $4.14 \pm 0.72 \mathrm{mg} / 100 \mathrm{~g}$ (red variety). These values are in agreement with those reported in other studies [58, 51]. However, they are higher in comparison to those [59]. The ash content is an indicator of the mineral content in the beans.

There was significant difference between the fibers content of the samples (Table 3). Authors have reported the crude fibers content of kidney beans as 4.2 per cent and 7.0 per cent respectively $[43,60]$. These values are less than the crude fibers content (5.35-5.45 mg/100g) obtained in the present study. Higher crude fibers content (7.87 and $8.16 \mathrm{mg} / 100 \mathrm{~g})$ has been found in kidney beans as compared to lentil (0.7 mg/100g), green gram (4.1 mg/100g), soyabean (3.7 $\mathrm{mg} / 100 \mathrm{~g})$ and cow pea $(3.8 \mathrm{mg} / 100 \mathrm{~g}$ ) also make them suitable for their use in preventing certain degenerative diseases like diabetes, cancer and heart disease [43]. 
There was significant difference between the starch content of the samples (Table 3). The starch is the most important chemical component in the flours. Apart from its energy contribution, starch in most of the processed food systems is known to contribute to the texture, and as a result, to the organoleptic properties of food [9].

Energy is essential for rest, activity and growth. Carbohydrate, protein and fat are three components which provide energy [43]. The data presented in Table 2 indicated that the purple bean (355.01 Kcal/ $100 \mathrm{~g}$ ) exhibited significantly higher value for physiological energy and the lowest physiological energy (308.39 Kcal/100g) has been observed in white beans. Authors have reported the energy value of kidney beans as $346 \mathrm{Kcal} / 100 \mathrm{~g}$ and $327 \mathrm{Kcal} / 100 \mathrm{~g}$ [43,61]. Researchers have reported that legumes could prevent or manage chronic health challenges such as diabetes, cardiovascular disease, cancer, obesity and contribute to overall health and wellness of human body [62].

Table 3 Proximate composition of two bean varieties (Phaseolus lunatus)

\begin{tabular}{lll}
\hline $\begin{array}{l}\text { Composition } \\
\text { (mg/100g) }\end{array}$ & Bean flours & \\
\cline { 2 - 3 } Moisture & $10.33 \pm 0.02^{\mathrm{a}}$ & White \\
Protein & $23.90 \pm 0.43^{\mathrm{a}}$ & $24.10 \pm 0.71^{\mathrm{a}}$ \\
Fat & $0.81 \pm 0.05^{\mathrm{a}}$ & $0.80 \pm 0.01^{\mathrm{a}}$ \\
Carbohydrates & $63.03 \pm 0.9^{\mathrm{a}}$ & $54.89 \pm 0.54^{\mathrm{b}}$ \\
Starch & $60.23 \pm 0.7^{\mathrm{a}}$ & $53.51 \pm 0.5^{\mathrm{b}}$ \\
Total sugar & $2.8 \pm 0.02^{\mathrm{a}}$ & $1.36 \pm 0.04^{\mathrm{b}}$ \\
Reducing sugar & $0.23 \pm 0.02^{\mathrm{a}}$ & $0.64 \pm 0.04^{\mathrm{b}}$ \\
Ash & $4.37 \pm 0.19^{\mathrm{a}}$ & $4.14 \pm 0.72^{\mathrm{a}}$ \\
Fibers & $5.35 \pm 0.45^{\mathrm{a}}$ & $5.45 \pm 0.45^{\mathrm{a}}$ \\
Energy (Kcal/100g) & $355.01^{\mathrm{a}}$ & $323.16^{\mathrm{b}}$ \\
\hline \multicolumn{2}{l}{ Values are means of triplicate determinations \pm standard deviation }
\end{tabular}

\subsection{Mineral composition}

Mineral composition of bean varieties (Phaseolus lunatus) flours are presented in table 4.

Different mineral composition may be due to differences in genes, geographical origin and growing environment in terms of e.g. rainfall pattern, soil fertility and temperature [63]. Minerals are fundamentally metals and other inorganic compounds that are essential for human nutrition and maintenance of certain physicochemical processes which are necessary to life. They play a critical role in the formation of skeletal structure, serving as essential co-factors for a number of enzymes and used for the utilization of nutrients and enzymes responsible for digestion and absorption [64].

The major minerals in the studied varieties were potassium and phosphorus which agrees with the observation of [65] on the potassium predominance in agricultural products. Similar observations have been reported for gingerbread plum [66] and lima bean seed coat [67] but contrary to the report on mucuna beans [16]. The samples are high in phosphorus and calcium, the minerals which are necessary for teeth and bone development in children [68].

Variation was observed in the quantitative composition of mineral elements in agreement [67] as a result of genetic variation and soil conditions. $\mathrm{Na} / \mathrm{K}$ ratio observed in this study is within the recommended level $(\leq 1.0)[11]$ and very vital in the prevention and management of high blood pressure. Ca/P ratio is high (high calcium, low phosphorus intake) only little amount of calcium will be loss through the urine, increasing the calcium level in bones. The Ca/P $(0.651$ to 0.659 ) ratio in the present study which is above 0.5 is an indication that the varieties evaluated are potential minerals sources for bone formation [69]. 
Table 4 Mineral composition of bean varieties (Phaseolus lunatus) flours

\begin{tabular}{lll}
\hline $\begin{array}{l}\text { Composition } \\
\text { (mg/100g) }\end{array}$ & \multicolumn{2}{l}{ Bean varieties } \\
\cline { 2 - 3 } Phosphorus & Purple & White \\
Calcium & $412 \pm 27^{\mathrm{a}}$ & $451.91 \pm 14.6^{\mathrm{b}}$ \\
Potassium & $268 \pm 0.12^{\mathrm{a}}$ & $297.84 \pm 2.4^{\mathrm{b}}$ \\
Sodium & $1444.7 \pm 4.8^{\mathrm{a}}$ & $1206.7 \pm 2.9^{\mathrm{b}}$ \\
Iron & $8.01 \pm 0.32^{\mathrm{a}}$ & $14.07 \pm 1.6^{\mathrm{b}}$ \\
$\mathrm{Ca} / \mathrm{P}$ & $15.22 \pm 0.32^{\mathrm{a}}$ & $73.7 \pm 3.7^{\mathrm{b}}$ \\
$\mathrm{Na} / \mathrm{K}$ & $0.65^{\mathrm{a}}$ & $0.66^{\mathrm{a}}$ \\
\hline & $0.006^{\mathrm{a}}$ & $0.012^{\mathrm{b}}$ \\
\hline
\end{tabular}

\section{Conclusion}

This study provided basic information on the composition and physical parameters of two wild bean varieties (Phaseolus lunatus). The white variety has the best characteristics (physical and physicochemical) and a reduced cooking time (45 min). Proteins, ash and fibers contents of both varieties present no significant difference ( $p<0.05)$. The mineral content differs significantly from one variety to another and the most dominant are potassium, phosphorus and calcium. The research results can be used by investigators and food businesses to develop recipes for processed bean foods, including fortified products.

\section{Compliance with ethical standards}

\section{Acknowledgments}

We express our gratitude to floristic center of Felix Houphouët Boigny University (Abidjan, Côte d'Ivoire) for their reception, availability and identification made of wild beans object of this research article.

\section{Disclosure of conflict of interest}

Ekissi ESG, Yapi JC, Kouadio TM, Gouledji AA and Kouame PL are not aware of any affiliations, memberships, funding, or financial holdings that might be perceived as constituting a conflict of interest.

\section{References}

[1] Baudet J. (1977). Origine et classification des espèces cultivées du genre Phaseolus bull Soc. Roy. Bot. Belg, 110, 65-76.

[2] Westphal E. (1974). Pulses in Ethiopia, their taxonomy and agricultural significance. Agricultural Research Reporte 815.Centre for Agricultural Publishing and Documentation; Wageningen Netherlands, 276.

[3] Kaplan L and Kaplan LN. (1988). Phaseolus in archeology, In P. Gepts ed. Genetic resources of Phaseolus beans, 125-142.

[4] Allen ON and Allen CK. (1981).The leguminosae: A source book of characteristics, uses and modulation. Macmillan Publishers Ltd., London, U.K, 5-29.

[5] Oliveira AC. (2006). Chemical composition, dietary fibers and resistant starch contents of raw and cooked pea, common bean, chickpea and lentil legumes. Food Chemistry, 94, 327-330.

[6] Shimelis EA and Rakshit SK. (2007). Effect of processing on antinutrients and in vitro protein digestibility of kidney bean (Phaseolus vulgaris L.) varieties grown in East Africa. Food Chem, 103, 161-72.

[7] Nciri N, El Mhamdi F, Ismail BH, Mansour BA and Fennira F. (2014). Physical Properties of Three White Bean Varieties (Phaseolus vulgaris L.) Grown in Tunisia. Journal of Applied Science and Agriculture, 9(11), 195-200. 
Ekissi et al. / World Journal of Advanced Research and Reviews, 2019, 03(02), 007-016

[8] Mackie WW. (1983). Origin, dispersal and variability of the Lima bean Phaseolus lunatus.Hilgardia, 15, 1-29.

[9] Tharanathan RN and Mahadevamma S. (2003). A review: grain legumes a boon to human nutrition. Trends in Food Science and Technology, 14, 507-518.

[10] Apyanwu AC. (1981). A Textbook of Agricultural. 1st Edition. African Educational Publisher (Nig), 103 - 104.

[11] Aremu MO, Olaofe 0 and Akintayo TEA. (2006). Comparative Study on the Chemical and Amino Acid Composition of some Nigeria Underutilized Legume Flours: Pakistan Journal of Nutrition, 5(1), 34 - 38.

[12] Rochfort S. and Panozzo J. (2007). Phytochemicals for health, the role of pulses. Journal of Agriculture Food Chemistry, 55, 7981-7994.

[13] Altuntas E and Demirtola H. (2007). Effect of moisture content on physical properties on some grain legume seeds. N. Z. J. Crop Horticult. Sci, 35, 423-433.

[14] AACC (2000). Approved methods of the AACC international. Methods 44-15A, 56-35, 76 13, and 08-16 (tenth ed.). St. Paul, MN: The Association.

[15] Wani IA, Sogi DS and Gill BS. (2013b). Physical and cooking characteristics of black gram (Phaseolus mungoo L.) cultivars grown in India. Int. J. Food Sci. Technol, 48, 2557-2563.

[16] Adebowale YA, Adeyemi A and Oshodi AA. (2005). Variability in physicochemical and antinutritional attributes of six Mucuna species. Food Chemistry, 89, 37-48.

[17] Bishnoi S and Khetarpaul N. (1993). Variability in physico-chemical properties and nutrient composition of different pea cultivars. Food Chemistry, 47(4), 371-373.

[18] AOAC 2000. Official methods of analysis of AOAC International (17th Ed.). Gaitherburg. USA: 29 AOAC International Inc.

[19] FAO. (1956). Acide cyanhydrique. Dosage par la méthode alcaline de titrage du manioc. In Food and Agriculture Organization of United Nations (Ed.), Traitement du Manioc, 84-85.

[20] Dubois M, Gilles KA, Hamilton JK, Rebers PA and Smith F. (1956). Colorimetric method for determination of sugars and related substances. Anal. Chem, 28, 350-356.

[21] Bertrand G. (1913). Dosage de sucres. In Dunod \& Pinat (Eds.), Guide pour les Manipulations de Chimie Biologie, 20.

[22] Jachertz R and Alexander N. (2011). Coping with Hunger? Vision of a Global Food System, 1930-1960. Journal of Global History, 6, 99-119.

[23] IITA. (1981), Analyses prélèvements pédologiques et végétaux (Manuel Nº1). International Institute of Tropical Agriculture, Ibadan.

[24] Tedesco MJ, Silva LMC, Higa RH. Silva FCda, Massruha and SMFS. (1999).Infra-estrutura, geracao e gerenciamento da informacao laboratorial. In: SILVA, F.C. da. Manual de analises quimicas de solos, plantas e fertilizantes. Brasilia: Embrapa Comunicacao para Transferencia de Tecnologia / Rio de Janeiro: Embrapa Solos / Campinas: Embrapa Informatica Agropecuaria, 317-369.

[25] Duncan DB. (1955). Multiple range and Multiple Ftests, Biometrics, 11, 1-42.

[26] Mirzaee E, Rafee S, Keyhani, A and Djom-Eh EZ. (2009). Physical properties of apricot to characterize best post harvesting options, Australian Journal of Crop Science, 3(2), 95- 100.

[27] Khadivi-Khub A. (2013). Analysis of Some Technological and Physical Characters of Mandarin (Citrus reticulata) Fruit in Iran, ISRN Agronomy, 4.

[28] Akaaimo DI and Raji A0. (2006). Some Physical and Engineering Properties of (Prosopis Africana) seed. Biosystems Engineering, 95(2), 197-205.

[29] Sirisomboon P, Kitchaiya P, Pholpho T and Mahuttanyavanitch W. (2007). Physical and mechanical properties of (Jatropha curcas L.) fruits, nuts and kernels. Biosystems Engineering, 97(2), 201-207.

[30] Wani AI, Sogi DS, Wani AA and Gill BS. (2017). Physical and cooking characteristics of some Indian kidney bean (Phaseolus vulgaris L.) cultivars. Journal of the Saudi Society of Agriculture Sciences, 16, 7-15.

[31] Appiah F, Asibuo JY and Kumah P. (2011). Physicochemical and functional properties of bean flours of three cowpea (VignaunguiculataL. Walp) varieties in Ghana. African. Journal of .Food Science, 5, 100-104. 
[32] Sobukola OP and Abayomi HT. (2011). Physical properties and rehydration characteristics of different varieties of maize (Zea mays L.) and cowpea (Vigna unguiculata (L.) Walp) Seed. J. Food Process. Preserv, 35(3), $299-307$.

[33] Esquivel M, Castineiras L and Hammer K. (1990). Origin, classification, variation and distribution of Limalima bean (Phaseolus lunatus L.) in the light of Cuban material. Euphytica, 49, 89-97.

[34] Chang KC and Satterlee LD. (1981). Isolation and Characterization of the Major Protein from Great Northern Beans (Phaseolus vulgaris). Journal of Food Science, 46(5), 1368-1373.

[35] Saha S, Singh G, Mahajan V and Gupta HS. (2009). Variability of nutritional and cooking quality in bean (Phaseolus vulgaris L.) as a function of genotype. Plant Foods Human Nutr, 64, 174-180.

[36] Bewley JD, Black M and Halmer P. (2006) The Encyclopedia of Seeds, Science, Technology and Uses. CABI Publishers, Cambridge, 509.

[37] SefaDedah S and Stanley DW. (1979). Textural implications of the microstructure of legumes. Food Technol, 33, 77-83.

[38] Ertas N. (2011). The Effects of Aqueous Processing on Some Physical and Nutritional Properties of Common Bean (Phaseolus vulgaris L.). International Journal of Health and Nutrition, 2(1), 21-27.

[39] Colas A. (1998). Définition de la qualité des farines pour les différentes utilisations. In Godon B., Will M C. Les industries de première transformation des céréales. Lavoisier. 679.

[40] Okonkwo SI and Opara MF. (2010). The Analysis of Bambara Nut (Voandzeia subterranea (L.) thouars) for Sustainability in Africa. Research Journal of Applied Sciences, 5(6), 394-396.

[41] Tavakoli H, Mohtasebi S, Rajabipour A and Tavakoli M. (2009). Efects of moisture content, loading rate, and grain orientation on fracture resistance of barley grain, Research in Agricultural Engineering, 55(3), 85-93.

[42] Mollazade K, Ahmadi H, Khorshidi J, Mohtasebi SS and Rajabipour A. (2009). Some Physical and Mechanical Properties of fennel seed (Foeniculum vulgare), Journal of Agricultural Science, 1(1), 66-75

[43] Gopalan C, Rama Sastri BV and Balasubramanian S. (2007). Nutritive Value of Indian Foods published by National Institute of Nutrition (NIN), ICMR.

[44] Chau CF, Cheung PCK and Wong YS. (1998). Chemical composition of three underutilized legume seeds grown in China. Food Chemistry, 61(4), 505-509.

[45] Myrene RD. (2013). Effect of traditional processing methods on nutritional quality of field bean, 4(3), 29-33.

[46] Osman MA. (2007). Changes in nutrient composition, tripsin inhibitor, phytate, tannins and protein digestibility of dolichos lablab (Lablab purpureus (L) Sweet) occurring during germination. Food Technology, 5(4), 294-299.

[47] Mortuza MG and Tzen JT. (2009). Physicochemical and functional properties of ten cultivars of seem (Lablab purpureus L.), an underexploited bean in Bangladesh. Journal of the Science of Food and Agriculture, 89(8), 1277-1283.

[48] Shaahu DT, Carew SN and Ikurior SA. (2015). Effect Of Processing On Proximate, Energy, Anti- Nutritional Factor, Amino Acid And Mineral Composition Of Lablab Seed. International Journal of Scientific \& Technology Research, 4(4), 1-4.

[49] Sridhar KR and Seena S. (2006). Nutritional and antinutritional significance of four unconventional legumes of the genus Canavalia - A comparative study. Food Chemistry, 99(2), 267-288.

[50] Oluwole A and Olayinka FA. (2011). Effects of Dehulling on Functional and Sensory Properties of Flours from Black Beans (Phaseolus vulgaris). Food and Nutrition Sciences, 2, 344-349.

[51] Barros MDe and Prudencio SH. (2016). Physical and chemical characteristics of common bean varieties. Semina: Ciências Agrárias, 37(2), 751-762.

[52] Marimuthu M, Sundaram U and Thirukannan S. (2016). Comparative study on proximate and phytochemical analysis of processed two different germplasm of Mucuna Pruriens (Velvet beans), 3(5), 229-233.

[53] Asif M, Rooney LW, Ali R and Riaz MN. (2013). Application and Opportunities of Pulses in Food System: A Review, Critical Reviews in Food Science and Nutrition, 53(11), 1168- 1179.

[54] Nakitto AM, Muyonga JH and Nakimbugwe D. (2015). Effects of combined traditional processing methods on the nutritional quality of beans. Food Science \& Nutrition, 3(3), 233- 241. 
[55] Nazni P and Devi SR. (2016). Effect of Processing on the Characteristics Changes in Barnyard and Foxtail Millet. J Food Process Technol, 7(3), 1-8.

[56] Sánchez-Chino X, Jiménez-Martínez, C, Dávila-Ortiz G, Álvarez-González I and Madrigal-Bujaidar E. (2015). Nutrient and Nonnutrient Components of Legumes, and Its Chemopreventive Activity: A Review. Nutrition and Cancer, 67(3), 401-410.

[57] Guzel D and Sayar S. (2012). Effect of cooking methods on selected physicochemical and nutritional properties of barlotto bean and Amino Acid Composition of some Nigeria Underutilized Legume Flours: Pakistan Journal of Nutrition, 5(1), $34-38$.

[58] Kamatchi KB, Tresina SP, Mohan VR and Vadivel V. (2010). Nutrient and Chemical Evaluation of Raw Seeds of Five Varieties of Lablab purpureus (L.) Sweet. Advances in Bioresearch, 1, 44-53.

[59] Hossain M, Bir AT, Tarique KM and Momen A. (2016). Disclosure of Green Banking Issues in the Annual Reports: A Study on Bangladeshi Banks. Middle East J. Bus, 11, 19-30.

[60] Bressani R, Elias LG and Navarrete DAJ. (1961). Nutritive value of Central American beans. IV. The essential amino acid content of samples of black beans, red beans, rice beans, and cowpeas of Guatemala. J. Food Sci, 26 (5), 525 528.

[61] Pant R and Tulsiani DRPJ. (1969). Toxic and teratogenic alkaloids of western range plants. Agric. Food Chem, 17(3), 473-482.

[62] Bassett C, Boye J, Tyler R and Oomah BD. (2010). Molecular, functional and processing characteristics of whole pulses and pulse fractions and their emerging food and nutraceutical applications. Food Research International, 43, 397-399.

[63] Beebe S, Gonzalez AV and Rengifo J. (2000). Research on trace minerals in the common beans. Food Nutr Bull, 21, 387-391.

[64] Gupta UC and Gupta SC. (2014). Sources and deficiency diseases of mineral nutrients in human health and nutrition: a review. Pedosphere, 24, 13-38.

[65] Olaofe 0 and Sanni CO. (1988). Mineral content of agricultural products. Food Chemistry, 30, 73-77.

[66] Amza T, Amadou I, Zhu K and Zhou H. (2011). Effect of extraction and isolation on physicochemical and functional properties of an underutilised seed protein: Gingerbread plum (Neocarya macrophylla). Food Research International, 44, 2843-2850.

[67] Seidu KT, Osundahunsi OF, Olaleye MT and Oluwalana, IB. (2015). Amino acid composition, mineral contents and protein solubility of some lima bean (Phaseolus lunatus L. Walp) Seeds Coat. Food Research International, 73, 130-134.

[68] David AB. (2006). Benders' dictionary of nutrition and food technology. 8th ed. England: Woodhead.

[69] Nieman DC, Butterworth DE and Nieman CN. (1992). Nutrition, Wmc Brown Publishers. Dubugye, USA, $237-312$.

\section{How to cite this article}

Ekissi ESG, Yapi JC, Kouadio MT, Gouledji AA and Kouame PL. (2019). Physical parameters and physico-chemical properties of two wild beans (Phaseolus lunatus) consumed in Côte d'Ivoire. World Journal of Advanced Research and Reviews, 3(2), 07-16. 